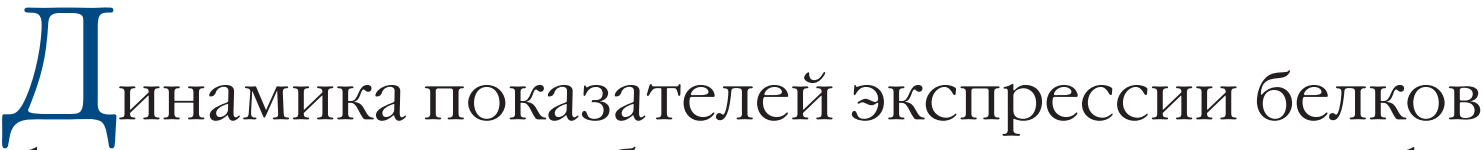 факторов роста у больных псориазом на фоне фототерапии
}

\author{
В.В. Чикин ${ }^{1}$, М.Б. Жилова', В.А. Смольянникова², М.А. Неседова'
}

1 ФГБУ «Государственный научный центр дерматовенерологии и косметологии» Минздрава России 107076, Москва, ул. Короленко, д. 3, стр. 6

2 ГБОУ ВПО «Первый Московский государственный медицинский университет им. И.М. Сеченова» Минздрава России

119991, Москва, ул. Трубецкая, д. 8, стр. 2

Цель. Изучить динамику показателей экспрессии белков фракторов роста у больных псориазом, получающих пуВАтерапию, влияние ПУВА-терапии на интенсивность зуда у больных псориазом, выраженность иннервации кожи и экспрессию в коже белков фракторов роста.

Материал и методы. Обследованы 30 больных обыкновенным псориазом, которым проводили лечение методом ПУВА-терапии. Степень тяжести псориаза оценивали с помощью индекса РASI, степень выраженности зуда — с помощью визуальной аналоговой шкалы до и после лечения. Экспрессию в коже семафорина-3А, амфирегулина, фактора роста нервов и маркера нервных волокон — белка PGP 9.5 определяли методом непрямой иммунофлюоресценции. Экспрессия белка PGP 9.5 была использована для оценки количества, средней длины, средней и суммарной интенсивности свечения нервных волокон.

Результаты. В эпидермисе больных псориазом выявлено повышение экспрессии амфирегулина и фактора роста нервов, увеличение количества, средней длины, средней и суммарной интенсивности свечения нервных волокон. После курса ПУВА-терапии отмечено уменьшение индекса PASI и выраженности зуда, снижение экспрессии амфирегулина и фактора роста нервов, количества и средней длины нервных волокон в эпидермисе. Выявлены прямые корреляционные связи между степенью выраженности зуда и уровнем экспрессии амфирегулина и фрактора роста нервов в эпидермисе, количеством и длиной нервных волокон в эпидермисе. Обнаружена прямая корреляционная связь уровня экспрессии в эпидермисе амфирегулина и фактора роста нервов со средней длиной нервных волокон в эпидермисе.

Заключение. У больных псориазом, получающих ПУВА-терапию, уменьшение интенсивности зуда происходит за счет снижения экспрессии в коже фрактора роста нервов и амсрирегулина.

Ключевые слова: псориаз, пУвА-терапия, нервные волокна, фактор роста нервов, амфирегулин. 


\title{
Dynamics of expression rates of growth factor proteins in psoriatic patients receiving a phototherapy
}

\author{
V.V. Chikin ${ }^{1}$, M.B. Zhilova ${ }^{1}$, V.A. Smolyannikova ${ }^{2}$, M.A. Nefedova ${ }^{1}$
}

${ }^{1}$ State Research Center of Dermatovenereology and Cosmetology, Ministry of Healthcare of the Russian Federation Korolenko str., 3, bldg 6, Moscow, 107076, Russia

${ }^{2}$ I.M. Sechenov First Moscow State Medical University

Trubetskaya str., 8, bldg 2, Moscow, 119991, Russia

\begin{abstract}
Goal. To study the dynamics of expression rates of growth factor proteins in psoriatic patients receiving the PUVA therapy. Materials and methods. The authors conducted a study of 30 patients with psoriasis vulgaris treated with the PUVA therapy. The psoriasis severity and extent of itching were assessed prior to and after the treatment by the PASI index and visual analogue scale, respectively. The expression of semaphorin 3A, amphiregulin, nerve growth factor and PGP 9.5 protein (a nerve fiber marker) in the skin was assessed by the indirect immunofluorescence method. The expression of PGP 9.5 protein was used to assess the quantity and mean length as well as average and total fluorescence intensity of nerve fibers.

Results. An increased expression of amphiregulin and nerve growth factor as well as increase in the quantity, mean length and average and total fluorescence intensity of nerve fibers were revealed in the epidermis of psoriatic patients. Following a course of the PUVA therapy, a decrease in the PASI index and extent of itching, reduced expression of amphiregulin and nerve growth factor as well as reduced quantity, mean length and average and total fluorescence intensity of nerve fibers in the epidermis were observed. Direct correlation dependence between the extent of itching, amphiregulin and nerve growth factor expression level and quantity and length of nerve fibers in the epidermis was discovered. Direct correlation dependence between the amphiregulin and nerve growth factor expression level, and average length of nerve fibers in the epidermis was discovered.

Conclusion. The itching intensity in psoriatic patients receiving the PUVA therapy is reduced due to the decreased skin expression of the nerve growth factor and amphiregulin.
\end{abstract}

Key words: psoriasis, PUVA therapy, nerve fibers, nerve growth factor, amphiregulin.

Corresponding author: chikin@cnikvi.ru. Vestnik Dermatologii i Venerologii 2015; 3: 87_95.

По данным ряда авторов, жалобы на зуд предъявляют от 64 до 97\% больных псориазом [1-9]. Как правило, при псориазе зуд ограничен очагами поражения кожи, однако у 20-30\% пациентов зуд отмечается на непораженной коже [1, 2, 9]. В ряде случаев у больных псориазом отмечается генерализованный зуд $[1,2,7]$.

Известно, что развитие зуда может быть обусловлено воздействием различных пруритогенов на окончания чувствительных нервных с-волокон [10, 11]. Формирование зуда определяется также выделением чувствительными нервными волокнами нейропептидов, способствующих развитию зуда, - субстанции $\mathrm{P}$ и пептида, связанного с геном кальцитонина (CGRP) [12-14]. Это подтверждается их избыточной продукцией в псориатической бляшке [15-23].
Интенсивность зуда зависит от выраженности иннервации кожи и функционального состояния чувствительных нервных волокон. Воздействие слабых пруритогенов и стимулов, которые в обычном состоянии не вызывают зуда, на чувствительные пруритоцептивные нервные с-волокна, находящиеся в состоянии нервной сенситизации, может приводить к развитию выраженного зуда [24-27]. Рост нервных волокон в коже контролируется белками - факторами роста [28]. Нейротрофин фрактор роста нервов и эпидермальный фрактор роста амфирегулин вызывают разрастание чувствительных нервных волокон [29-32]. Фактор редукции нервов семафорин-ЗА действует противоположным образом, отклоняя конус роста нерва и тем самым уменьшая выраженность иннервации [33, 34]. 
Для терапии зуда используются блокаторы Н1гистаминовых рецепторов, однако при хронических воспалительных заболеваниях кожи их эффрективность недостаточна [11]. Противозудный эффрект некоторых методов фрототерапии продемонстрирован у пациентов с различными заболеваниями кожи и других органов и систем. Показано, что фототерапия больных атопическим дерматитом приводит не только к разрешению высыпаний, но и к уменьшению зуда [35-40]. Уменьшение зуда при использовании УФА1фототерапии, узкополосной фототерапии 311 нм и ПУВА-терапии было отмечено у больных узловатым пруриго [41-43]. Узкополосная фототерапия $311 \mathrm{Hм}$ приводила к уменьшению зуда у больных Т-клеточной лимфомой кожей, лимфомой Ходжкина, истинной полицитемией [44-46]. Показана эффрективность фототерапии при зуде у больных ВИЧ-инфекцией и при хронической почечной недостаточности $[47,48]$.

Уменьшение зуда под влиянием фототерапии может быть связано с ее противовоспалительным действием и уменьшением выраженности воспалительной реакции в коже. Однако в экспериментах показана способность УФ-излучения уменьшать выраженность иннервации кожи [49]. Применение фототерапии при атопическом дерматите приводит к снижению у больных интенсивности зуда и уменьшению числа нервных волокон в коже, особенно в эпидермисе [50]. В связи с этим противозудный эффект фототерапии связывается с уменьшением количества пруритоцептивных чувствительных нервных волокон в коже [51]. J. Wallengren и F. Sundler (2004), обследовав 4 больных псориазом после курса фототерапии, обнаружили у них исчезновение зуда и уменьшение числа нервных волокон в эпидермисе [51]. В то же время согласно имеющимся данным, у больных псориазом при проведении ПУВА-терапии и узкополосной средневолновой фототерапии отмечается развитие зуда как нежелательного явления [52, 53].

Цель исследования - изучить влияние ПУВА-терапии на интенсивность зуда у больных псориазом, выраженность иннервации кожи и экспрессию в коже белков фракторов роста.

\section{Материал и методы}

Проведено клиническое обследование 30 больных обыкновенным псориазом (9 женщин и 21 мужчина в возрасте от 21 года до 68 лет). Для оценки степени тяжести течения заболевания у больных обыкновенным псориазом использовали индекс PASI. C помощью визуальной аналоговой шкалы у больных обыкновенным псориазом определяли степень выраженности зуда, которую оценивали от 0 до 10 баллов. Отсутствию зуда соответствовало 0 баллов. Зуд расценивали как слабый, если степень его выраженности, согласно визуальной аналоговой шкале, составляла от 1 до 3, как умеренный - от 4 до 7 и как выражен- ный - от 8 до 10 баллов. Диагноз обыкновенного псориаза был подтвержден патоморфологически.

Для лечения больных обыкновенным псориазом назначалась ПУВА-терапия с пероральным приемом фотосенсибилизатора (амми большой плодов фурокумарины). В течение 4 нед. проводили 16 процедур ПУВА-терапии, после чего повторно оценивали состояние больных.

Определяли экспрессию фактора роста нервов, амфирегулина и семафорина-ЗА в эпидермисе и белка PGP 9.5 в эпидермисе и дерме больных псориазом до и после лечения методом непрямой иммунофлюоресценции с применением конфокальной микроскопии in vitro. Исследования проводили на криостатных срезах согласно разработанному протоколу [54]. Оценка количественных параметров экспрессии белка PGP 9.5, фрактора роста нервов, амфирегулина и семафорина-ЗА проводилась с использованием базового комплекта программы Olympus Fluoview Ver. 1.7b.

Поскольку белок продукта гена PGP 9.5 является маркером нервных волокон, его экспрессия использовалась для определения количества и средней длины нервных волокон, средней и суммарной интенсивности свечения нервных волокон в эпидермисе, на границе эпидермиса и дермы, в дерме больных псориазом и в препарате кожи в целом. Средняя и суммарная интенсивность свечения позволяла оценить уровень активности нейронов. Для оценки количественных показателей экспрессии белка PGP 9.5 сначала определяли локализацию PGP 9.5-позитивных нервных волокон в поле зрения (в эпидермисе, дерме, зоне дермоэпидермальной границы), затем измеряли показатель интенсивности свечения для каждого волокна по заданному каналу (в условных единицах), суммировали показатель интенсивности свечения для каждого поля зрения. В пределах одного биоптата выделяли по три поля зрения, для каждого из них рассчитывался средний показатель экспрессии белка PGP 9.5. При измерении количественных показателей экспрессии фактора роста нервов, амфирегулина и семафоринаЗА в поле зрения произвольным образом выделяли три одинаковые по площади зоны квадратной фрормы, в которых определялся средний показатель интенсивности свечения по заданному каналу (в условных единицах). Контрольную группу составили 25 здоровых людей.

Статистическую обработку полученных данных проводили с помощью программы Statistica 10. Для сравнения данных, полученных при обследовании группы больных псориазом и контрольной группы, использовали критерий Манна - Уитни. Для сравнения данных, полученных при обследовании больных псориазом до и после лечения, использовали критерий Уилкоксона. Данные представляли в виде $M \pm m$. Различия считали достоверными при уровне статистиче- 
ской значимости $p<0,05$. С помощью рангового коэффрициента корреляции Спирмена выявляли корреляционные связи между клиническими показателями степени тяжести псориаза и выраженности зуда и уровнем экспрессии в эпидермисе фрактора роста нервов, амфирегулина, семафорина-ЗА, а также количеством, длиной, средней и суммарной интенсивностью свечения нервных волокон в коже больных. Выявляли также корреляционные связи между выраженностью экспрессии в эпидермисе белков амфиирегулина, семафорина ЗА, фрактора роста нервов и количеством, длиной, средней и суммарной интенсивностью свечения нервных волокон в коже больных псориазом.

\section{Результаты}

Длительность заболевания у больных псориазом составляла от 3 до 44 лет (в среднем 16,17 $\pm 2,21$ года). При обследовании 30 больных обыкновенным псориазом было выявлено, что индекс PASI составлял от 10,2 до 57 (в среднем 23,95 $\pm 1,94$ ).

Степень выраженности зуда у больных псориазом составила от 0 до 10 баллов (в среднем 6,00 \pm 0,48 балла). Среди больных псориазом зуд отсутствовал у 1 (3,33\%) человека, слабый зуд был у 4 (13,33\%) больных, умеренный зуд - у 18 (60,00\%), выраженный зуд - у 7 (23,34\%).

После курса ПУВА-терапии индекс PASI у больных псориазом составлял от 0,6 до 22,7. Отмечено статистически значимое уменьшение индекса PASI у больных псориазом с 23,95 \pm 1,94 до 5,14 \pm 0,89 ( $p<0,05)$. Уменьшение показателя PASI на $75 \%$ и более после курса ПУВА-терапии было достигнуто у 83,33\% больных псориазом.

Выраженность зуда у больных псориазом после курса ПУВА-терапии составляла от 0 до 6 баллов. Выявлено статистически значимое уменьшение выраженности зуда у больных псориазом с 6,0 \pm 0,48 до 0,93 $\pm 0,30$ балла $(p<0,05)$. После терапии ни у одного больного псориазом не отмечалось выраженного зуда, умеренный зуд имел место у 3 (10,00\%) больных, слабый - у 8 (26,67\%) больных. У 19 (63,33\%) больных псориазом после лечения зуд отсутствовал (рис. 1).

При проведении исследований методом непрямой иммунофрлюоресценции с применением конфокальной in vitro микроскопии у больных псориазом было выявлено статистически значимое повышение экспрессии амфирегулина в эпидермисе - 195,64 \pm 16,99 усл. ед. по сравнению с контролем - 109,9 $\pm 24,71$ усл. ед. $(p<0,05)$. Кроме того, в эпидермисе больных псориазом была статистически значимо повышена экспрессия фрактора роста нервов - 695,64 \pm 46,80 усл. ед. по сравнению с контролем - 485,5 \pm 75,1 усл. ед. $(p<0,05)$ (табл. 1).

У больных псориазом было выявлено статистически значимое увеличение числа нервных волокон в эпидермисе $-9,27 \pm 1,10$ по сравнению с контролем - 1,0 0,55 ( $p<0,05)$, на границе эпидермиса и дермы - 13,10 $\pm 1,43$, в контроле - 6,80 $\pm 2,17$ $(p<0,05)$ и в препарате кожи $-34,57 \pm 2,16$, в контроле $-21,40 \pm 5,90(p<0,05)$. Средняя длина нервных волокон в эпидермисе больных псориазом $28,76 \pm 2,88$ нм была статистически значимо больше, чем в контроле, $-9,07 \pm 4,53$ нм $(p<0,05)$ (табл. 2).

В эпидермисе больных псориазом наблюдалось также статистически значимое повышение средней интенсивности свечения нервных волокон - $1080 \pm 31,39$ усл. ед. по сравнению с контролем - 548,1 $\pm 220,1$ усл. ед. $(p<0,05)$ и суммарной интенсивности свечения нервных волокон - $64224 \pm 7909$ усл. ед. по сравнению с контролем - $22624 \pm 10523$ усл. ед. ( $<<0,05)$ (табл. 3).

После курса ПУВА-терапии у больных псориазом было отмечено статистически значимое уменьшение экспрессии эпидермального фактора роста амфирегулина с 195,64 \pm 16,99 до 151,83 \pm 12,86 усл. ед. $(p<0,05)$ (рис. 2). Также выявлено достоверное уменьшение экспрессии нейротрофина фрактора роста нервов с 695,64 \pm 46,80 до 521,80 \pm 41,87 усл. ед. $(p<0,05)$ (рис. 3).

После лечения у больных псориазом было также обнаружено статистически значимое уменьшение количества нервных волокон в эпидермисе с $9,27 \pm 1,10$ до $5,30 \pm 0,62(p<0,05)$, в дерме с $13,07 \pm 0,81$ до $10,17 \pm 0,75(p<0,05)$ и в препарате в целом - с 34,57 $\pm 2,16$ до 27,17 $\pm 1,87$ ( $p<0,05)$. Средняя длина нервных волокон после лечения

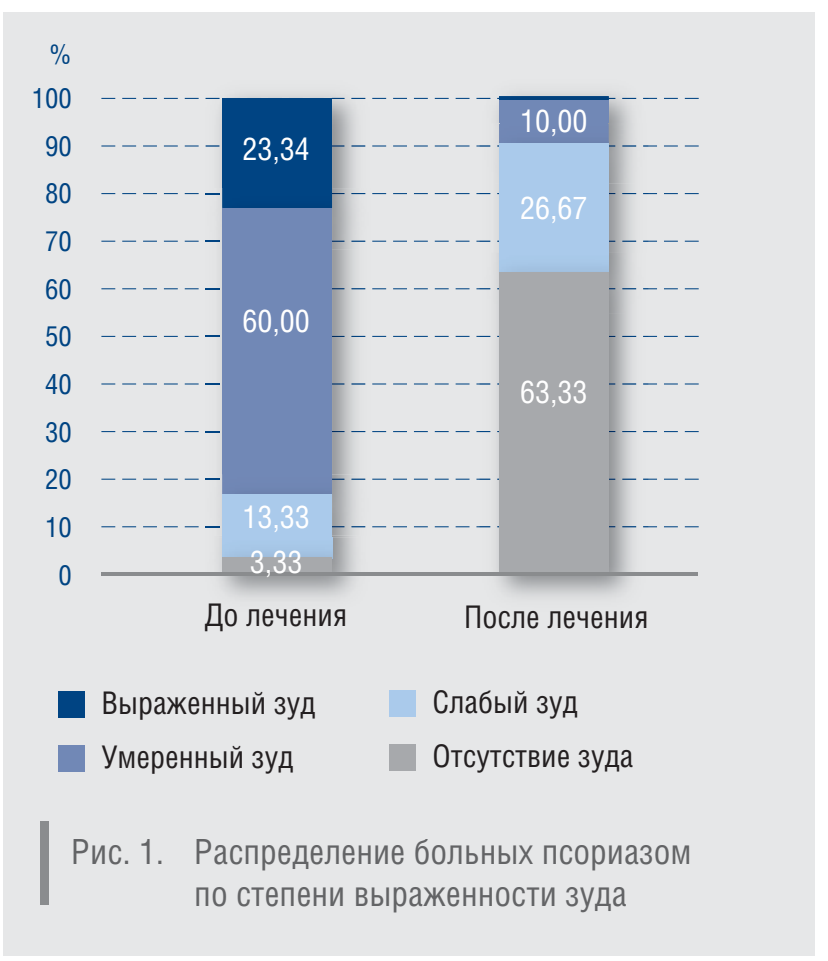


Таблица 1 П Показатели экспрессии амсрирегулина, семафорина-3А и фрактора роста нервов в эпидермисе больных псориазом

\begin{tabular}{lccc}
\hline \multirow{2}{*}{ Показатель } & \multicolumn{2}{c}{ Больные псориазом $(n=30)$} & \multirow{2}{*}{ Контроль $(n=25)$} \\
\cline { 2 - 3 } & до лечения & после лечения & $109,9 \pm 24,71$ \\
\hline Амфирегулин & $195,64 \pm 16,99^{*}$ & $151,83 \pm 12,86^{\star *}$ & $178,3 \pm 23,81$ \\
\hline Семасрорин-3А & $229,62 \pm 12,71$ & $221,95 \pm 10,98$ & $485,5 \pm 34,53$ \\
\hline Фактор роста нервов & $695,64 \pm 46,80^{*}$ & $521,80 \pm 41,87^{* *}$ & 4 \\
\hline
\end{tabular}

Примечание. * - статистически значимое отличие от контрольной группы $(p<0,05) ;{ }^{*}$ * — статистически значимое отличие от показателя до лечения $(p<0,05)$.

уменьшилась только в эпидермисе - с 28,76 $\pm 2,88$ до $21,19 \pm 1,97$ нм $(p<0,05)$ (рис. 4).

Статистически значимых изменений средней и суммарной интенсивности свечения нервных волокон в эпидермисе, на границе эпидермиса и дермы, в дерме и в препарате суммарно после курса ПУВАтерапии не обнаружено.

Корреляционный анализ показал, что степень тяжести псориаза, оцененная с помощью индекса PASI, прямо коррелировала с уровнем экспрессии амфирегулина в коже $(\rho=0,497, p=0,005)$, длиной нервных волокон в эпидермисе ( $\rho=0,362, p=0,049)$, средней интенсивностью свечения нервных волокон в эпидермисе $(\rho=0,420, p=0,02)$. Степень тяжести заболевания у больных псориазом прямо коррелировала также с суммарной интенсивностью свечения нервных волокон в дерме $(\rho=0,364, p=0,048)$ и с суммарной интенсивностью свечения нервных волокон в препарате кожи $(\rho=0,411, p=0,024)$.
Также выявлена прямая корреляционная связь между степенью выраженности зуда у больных псориазом и уровнем экспрессии эпидермального фрактора роста амфирегулина в коже $(\rho=0,508, p=0,004)$, уровнем экспрессии нейротрофина фрактора роста нервов в коже $(\rho=0,640, p=0,0001)$, количеством и длиной нервных волокон в эпидермисе $(\rho=0,660, p=0,00007$; $\rho=0,557, p=0,001$ соответственно).

Выраженность экспрессии амфирегулина в эпидермисе больных псориазом прямо коррелировала со средней длиной нервных волокон в дерме $(\rho=0,539, p=0,002)$, в эпидермисе $(\rho=0,473$, $p=0,008)$ и в препарате кожи $(\rho=0,375, p=0,04)$, а также со средней интенсивностью свечения нервных волокон в эпидермисе ( $\rho=0,414, p=0,023)$, на границе эпидермиса и дермы $(\rho=0,421, p=0,02)$ и в препарате кожи $(\rho=0,369, p=0,044)$. Обнаружена прямая корреляционная связь между экспрессией амфрирегулина в коже больных псориазом и сум-

Таблица 2 Количество и средняя длина нервных волокон в препаратах кожи больных псориазом

\begin{tabular}{|c|c|c|c|}
\hline \multirow{2}{*}{ Показатель } & \multicolumn{2}{|c|}{ Больные псориазом $(n=30)$} & \multirow{2}{*}{ Контроль $(n=25)$} \\
\hline & до лечения & после лечения & \\
\hline \\
\hline в эпидермисе & $9,27 \pm 1,10^{*}$ & $5,30 \pm 0,62^{* *}$ & $1,0 \pm 0,55$ \\
\hline на границе эпидермиса и дермы & $13,10 \pm 1,43^{*}$ & $11,60 \pm 1,05$ & $6,80 \pm 2,17$ \\
\hline в дерме & $13,07 \pm 0,81$ & $10,17 \pm 0,75^{\text {* * }}$ & $13,60 \pm 3,84$ \\
\hline в препарате кожи & $34,57 \pm 2,16^{*}$ & $27,17 \pm 1,87^{\star *}$ & $21,40 \pm 5,90$ \\
\hline \multicolumn{4}{|l|}{ Средняя длина нервных волокон, нм: } \\
\hline на границе эпидермиса и дермы & $30,76 \pm 2,82$ & $25,10 \pm 1,92$ & $20,86 \pm 4,69$ \\
\hline в дерме & $28,03 \pm 2,40$ & $25,57 \pm 2,08$ & $21,77 \pm 2,31$ \\
\hline в препарате кожи & $30,45 \pm 2,53$ & $24,42 \pm 1,73$ & $23,31 \pm 1,63$ \\
\hline
\end{tabular}

Примечание. * - статистически значимое отличие от контрольной группы $(p<0,05) ;$ ** — статистически значимое отличие от показателя до лечения $(p<0,05)$. 
Таблица 3 Средняя и суммарная интенсивность свечения нервных волокон в коже больных псориазом

\begin{tabular}{|c|c|c|c|}
\hline \multirow{2}{*}{ Показатель } & \multicolumn{2}{|c|}{ Больные псориазом ( $n=30)$} & \multirow{2}{*}{ Контроль $(n=25)$} \\
\hline & до лечения & после лечения & \\
\hline \multicolumn{4}{|c|}{ Средняя интенсивность свечения нервных волокон: } \\
\hline в эпидермисе & $1080 \pm 31,39^{*}$ & $977,7 \pm 55,02$ & $548,1 \pm 220,1$ \\
\hline на границе эпидермиса и дермы & $1176 \pm 25,92$ & $1140 \pm 26,76$ & $1146 \pm 163,0$ \\
\hline в дерме & $1255 \pm 33,62$ & $1199 \pm 20,42$ & $1267 \pm 84,54$ \\
\hline в препарате кожи & $1173 \pm 27,0$ & $1122 \pm 21,13$ & $1233 \pm 75,79$ \\
\hline \multicolumn{3}{|c|}{ Суммарная интенсивность свечения нервных волокон: } & $22624 \pm 10523$ \\
\hline на границе эпидермиса и дермы & $73998 \pm 8521$ & $76271 \pm 20085$ & $56117 \pm 14495$ \\
\hline в дерме & $70674 \pm 8906$ & $59701 \pm 5312$ & $51858 \pm 5407$ \\
\hline в препарате кожи & $71580 \pm 7724$ & $57599 \pm 3998$ & $55248 \pm 3466$ \\
\hline
\end{tabular}

Примечание. * — статистически значимое отличие от контрольной группы $(p<0,05)$.

марной интенсивностью свечения нервных волокон в препарате кожи $(\rho=0,396, p=0,044)$.

У больных псориазом была также выявлена прямая корреляционная связь между выраженностью экспрессии фактора роста нервов и количеством нерв- ных волокон в эпидермисе ( $\rho=0,413, p=0,023)$, средней длиной нервных волокон в эпидермисе $(\rho=0,379$, $p=0,039)$, средней длиной нервных волокон в препарате кожи $(\rho=0,409, p=0,025)$. Выраженность экспрессии фрактора роста нервов прямо коррелировала

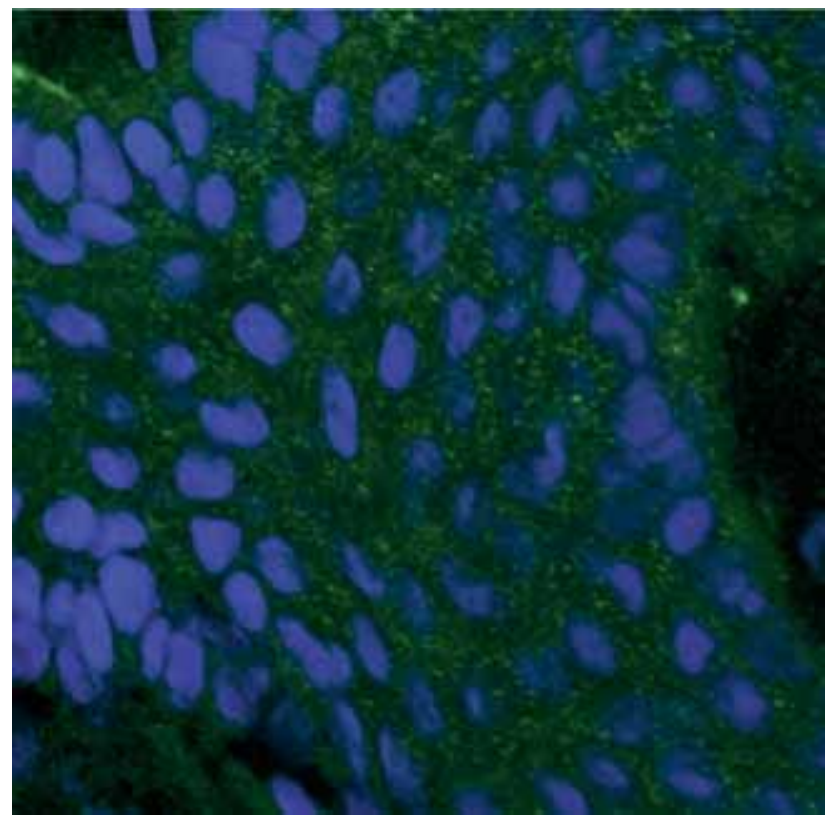

a

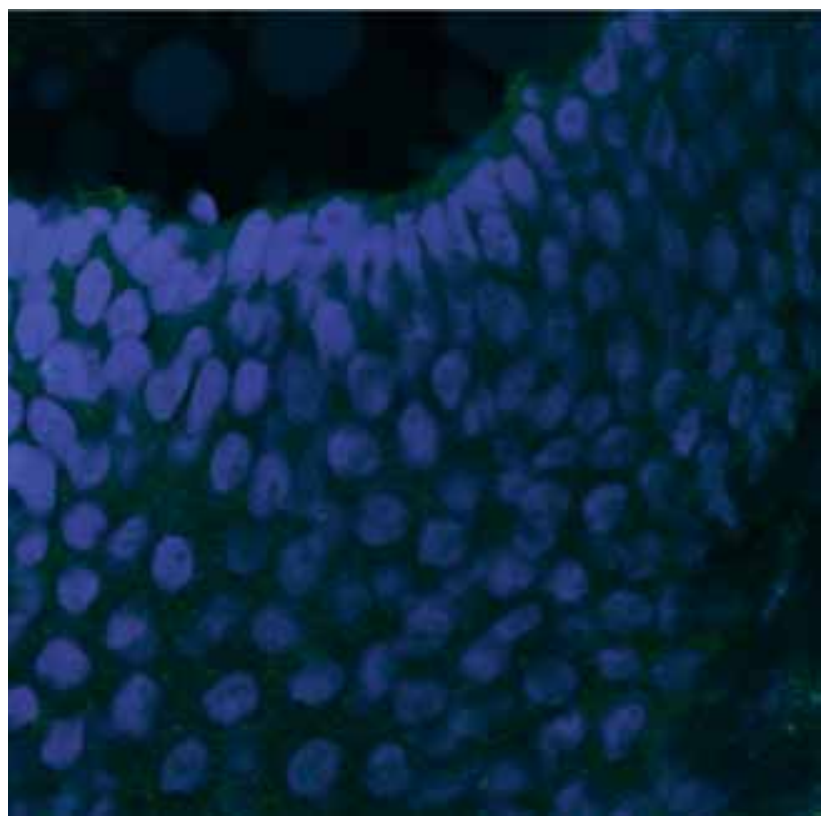

$\sigma$

Рис. 2 Экспрессия амфрирегулина (зеленое свечение) в эпидермисе больного обыкновенным псориазом до лечеРис. 2. ния (а), отсутствие экспрессии амфирегулина после ПУВА-терапии (б). Реакция непрямой иммунофлюоресценции, × 600 


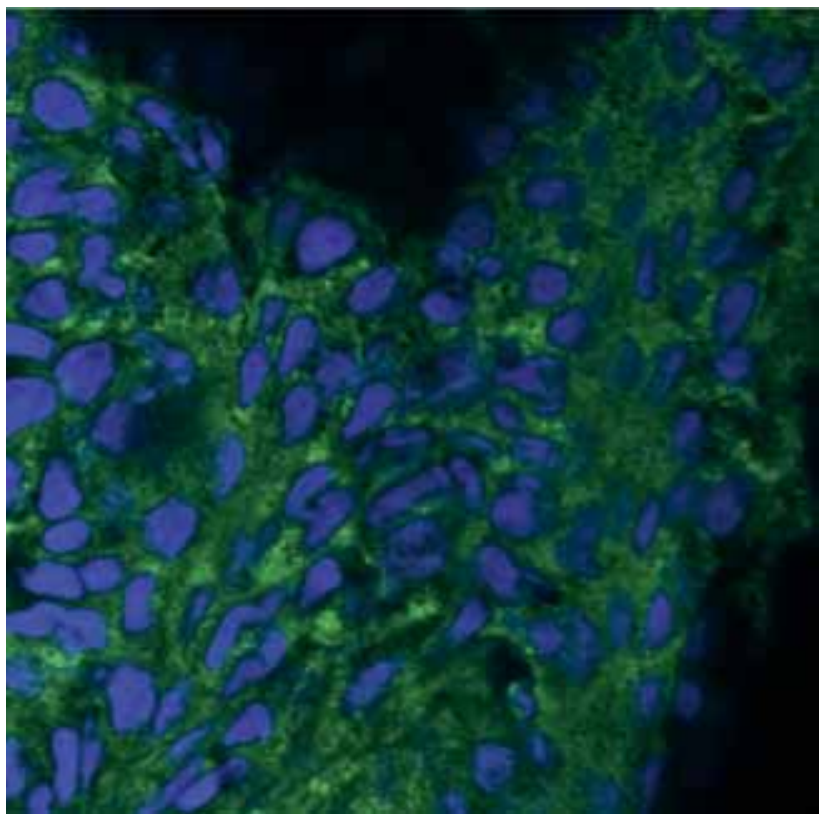

a

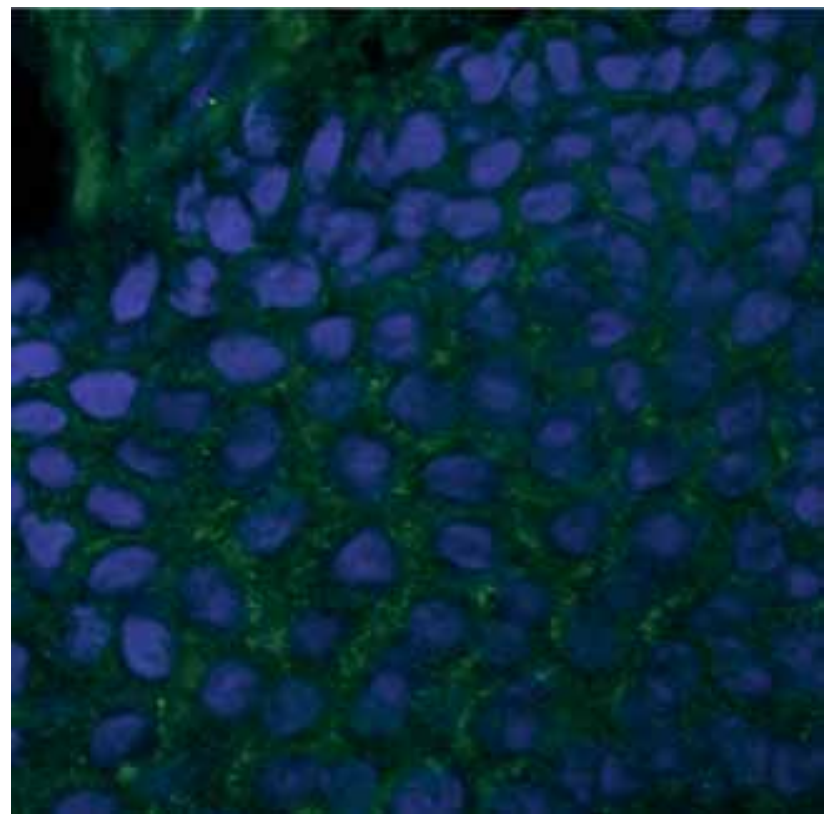

6

Рис. 3. Экспрессия фрактора роста нервов (зеленое свечение) в эпидермисе больного обыкновенным псориазом: выраженная до лечения (а) и слабовыраженная после ПУВА-терапии (б).

Реакция непрямой иммунофлюоресенции, × 600

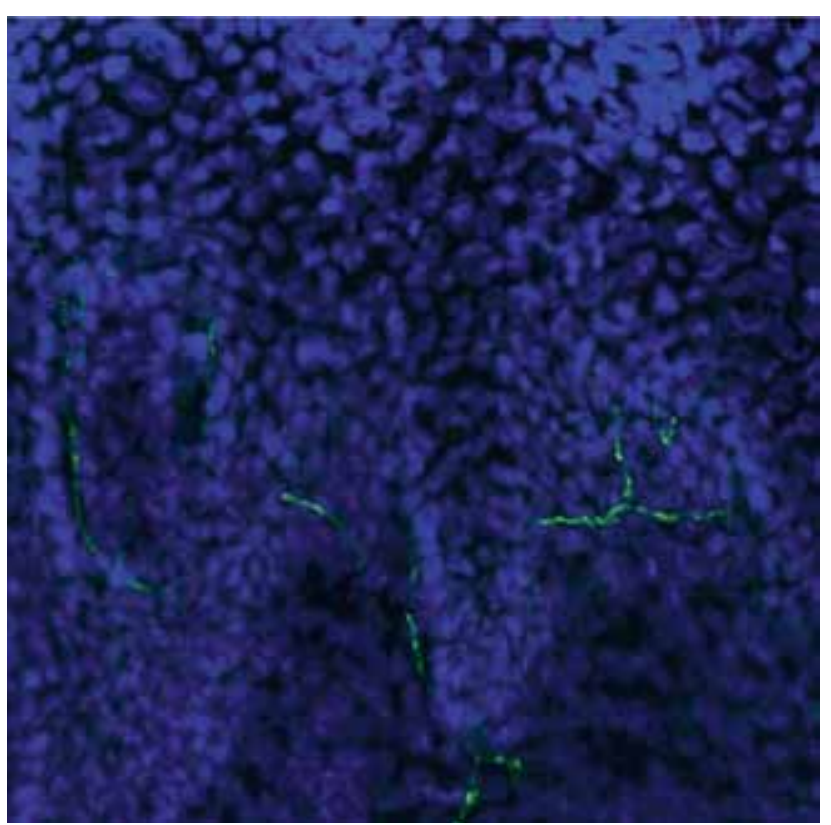

a

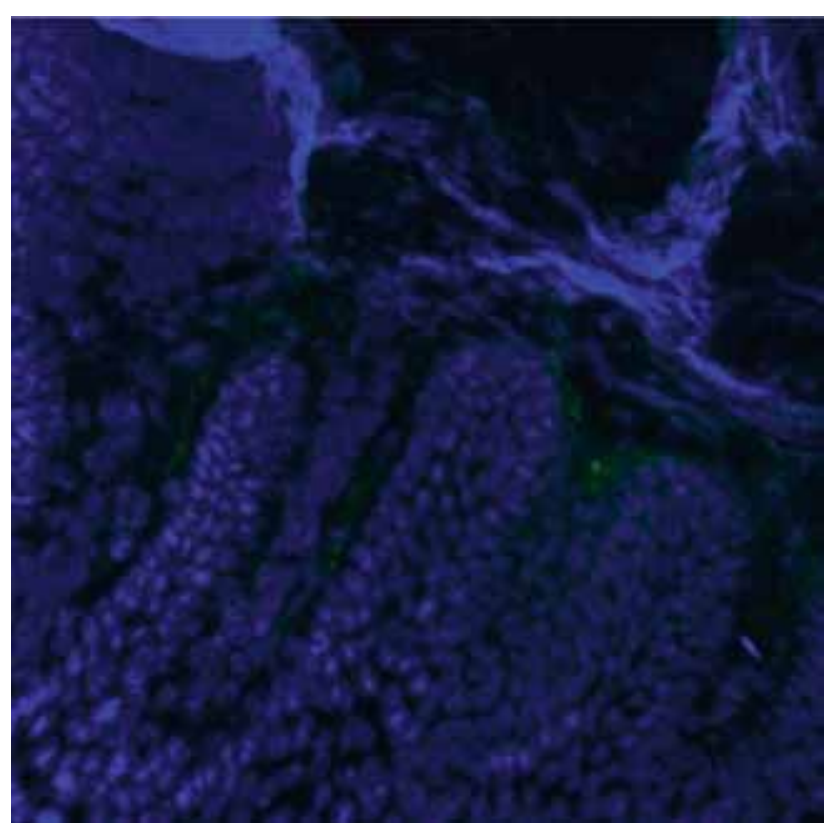

$\sigma$

Рис 4 Нервные волокна (зеленое свечение) в эпидермисе больного обыкновенным псориазом (а) до лечения; отсутствие нервных волокон в эпидермисе после ПУВА-терапии (б).

Реакция непрямой иммунофлюоресценции, $\times 200$ 
также со средней интенсивностью свечения нервных волокон в эпидермисе больных псориазом $(\rho=0,390$, $p=0,033)$, с суммарной интенсивностью свечения нервных волокон в эпидермисе $(\rho=0,410, p=0,024)$, на границе эпидермиса и дермы $(\rho=0,400, p=0,028)$ и в препарате кожи ( $\rho=0,373, p=0,042)$.

\section{Обсуждение}

Выявлено, что интенсивность зуда у больных псориазом находится в прямой корелляционной связи с количеством и средней длиной нервных волокон в эпидермисе, уровнем экспрессии в коже фактора роста нервов и амфирегулина.

После курса ПУВА-терапии у больных псориазом статистически значимо уменьшается степень выраженности зуда, количество и средняя длина нервных волокон в эпидермисе, экспрессия фрактора роста нервов и амфрирегулина в коже больных.

Полученные результаты свидетельствуют о способности ПУВА-терапии не только приводить к регрессу высыпаний у больных псориазом, но и уменьшать степень выраженности зуда.

Обнаружено, что у больных псориазом повышены количество, средняя длина, средняя и суммарная интенсивность свечения нервных волокон в эпидермисе. Выявленная прямая корреляционная связь степени выраженности зуда с количеством и средней длиной нервных волокон в эпидермисе больных псориазом указывает на значение выраженности иннервации эпидермиса в развитии зуда при псориазе.

Это подтверждается уменьшением количества и средней длины нервных волокон в эпидермисе больных псориазом после курса ПУВА-терапии.

Причиной повышения иннервации эпидермиса может быть продукция белков, способствующих росту нервных волокон. Нами обнаружен повышенный уровень экспрессии в эпидермисе больных псориазом нейротрофина фрактора роста нервов и эпидермально- го фрактора роста амфрирегулина. Выявленная прямая корреляционная связь между экспрессией фрактора роста нервов в эпидермисе и количеством, средней длиной, средней и суммарной интенсивностью свечения нервных волокон в эпидермисе указывает на значение фрактора роста нервов в разрастании нервных волокон у больных псориазом. Продемонстрирована роль амфирегулина в разрастании нервных волокон в эпидермисе больных псориазом. Об этом свидетельствует выявленная прямая корреляционная связь между выраженностью экспрессии амфрирегулина в эпидермисе и средней длиной, средней и суммарной интенсивностью свечения нервных волокон в эпидермисе больных псориазом.

Значение фрактора роста нервов и амфирегулина в развитии у больных псориазом зуда, ассоциированного с повышением иннервации эпидермиса, подтверждается также выявлением прямой корреляционной связи между степенью выраженности зуда и уровнем экспрессии этих белков в коже, а также уменьшением под влиянием ПУВА-терапии не только степени выраженности зуда и иннервации эпидермиса, но и экспрессии фактора роста нервов и амфирегулина в коже больных. Данных о влиянии фрактора редукции нервов семафорина-ЗА на выраженность иннервации кожи больных псориазом выявлено не было.

\section{Заключение}

Таким образом, ПУВА-терапия приводит к снижению выраженности зуда у больных псориазом за счет уменьшения иннервации эпидермиса. Уменьшение выраженности иннервации эпидермиса у больных псориазом происходит в результате снижения под влиянием ПУВА-терапии экспрессии в эпидермисе белков, способствующих росту нервных волокон, - нейротрофина фрактора роста нервов и эпидермального фрактора роста амфирегулина. I

\section{Литература}

1. Yosipovitch G., Goon A., Wee J. et al. The prevalence and clinical characteristics of pruritus among patients with extensive psoriasis. Br J Dermatol 2000; 143: 969-973.

2. Szepietowski J.C., Reich A., Wiśnicka B. Itching in patients suffering from psoriasis. Acta Derm Venereol Croat 2002; 10 (4): 221-226.

3. Reich A., Szepietowski J.C, Wiśnicka B., Pacan P. Does stress influence itching in psoriatic patients? Dermatol Psychosom 2003; 4: 151_-155

4. Reich A., Orda A., Wiśnicka B., Szepietowski J.C. Plasma neuropeptides and perception of pruritus in psoriasis. Acta Derm Venereol 2007; 87: 299_-304.

5. Sampogna F., Gisondi P., Melchi C.F. et al. Prevalence of symptoms by patients with different clinical types of psoriasis. Br J Dermatol 2004; 151: 594—599.
6. Chang S.-E., Han S.-S., Jung H.-J., Choi J.-H. Neuropeptides and their receptors in psoriatic skin in relation to pruritus. Br J Dermatol 2007; 156: 1272—1277.

7. Amatya B., Wennersten G., Nordlind K. Patients' perspective of pruritus in chronic plaque psoriasis: a questionnaire-based study. J Eur Acad Dermatol Venereol 2008; 22: 822 - 826.

8. Bilac C., Ermertcan A.T., Bilac D.B. et al. The relationship between symptoms and patient characteristics among psoriasis patients. Ind J Dermatol Venereol Leprol 2009; 75: 551 .

9. Prignano F., Ricceri F., Pescitelli L., Lotti T. Itch in psoriasis: epidemiology, clinical aspects and treatment options. Clin Cosmet Investig Dermatol 2009; 2: 9-13.

10. Ikoma A., Steinhoff M., Ständer S. et al. The neurobiology of itch. Nat Rev Neurosci 2006; 7 (7): 535—547.
11. Garibyan L., Rheingold C.G., Lerner E.A. Understanding the pathophysiology of itch. Dermatol Ther 2013; 26 (2): 84-91.

12. Shepherd A.J., Downing J.E., Miyan J.A. Without nerves, immunology remains incomplete - in vivo veritas. Immunology 2005; 116: 145-163.

13. Raap U., Kapp A. Neuroimmunological findings in allergic skin diseases. Curr Opin Allergy Clin Immunol 2005: 5: 419-424.

14. Buddenkotte J., Steinhoff M. Pathophysiology and therapy of pruritus in allergic and atopic diseases. Allergy 2010; 65: 805-821.

15. Eedy D.J., Johnston C.F., Shaw C., Buchanan K.D. Neuropeptides in psoriasis: an immunocytochemical and radioimmunoasay study. J Invest Dermatol 1991; 96: 434-438. 
16. Naukkarinen A., Harvima I., Paukkonen K. et al. Immunohistochemical analysis of sensory nerves and neuropeptides, and their contacts with mast cells in developing and mature psoriatic lesions. Arch Dermatol Res 1993; 285: 341—346.

17. Glinski W., Brodecka H., Glinska-Ferenz M., Kowalski D. Neuropeptides in psoriasis: possible role of beta-endorphin in the pathomechanism of the disease. Int J Dermatol 1994; 33: 356—360.

18. Al'Abadie M.S., Senior H.J., Bleehen S.S., Gawkrodger D.J. Neuropeptides and general neuronal marker in psoriasis - an immunohistochemical study. Clin Exp Dermatol 1995; 20: 384-389.

19. Chan J., Smoller B.R., Raychauduri S.P. et al. Intraepidermal nerve fiber expression of calcitonin generelated peptide, vasoactive intestinal peptide and substance $P$ in psoriasis. Arch Dermatol Res 1997; 289: $611-616$

20. Jiang W.-Y., Raydchaudhuri S.P., Farber E.M. Double-labelled immunofluorescence study of cutaneous nerves in psoriasis. Int J Dermatol 1998; 37: 572 - 574.

21. Staniek V., Doutremepuich J., Schmitt D. et al. Expression of substance $P$ receptors in normal and psoriatic skin. Pathobiology 1999; 67: 51-54.

22. He Y., Ding G., Wang X. et al. Calcitonin gene-related peptide in Langerhans cells in psoriatic plaque lesions. Chin Med J 2000; 113: 747_-751.

23. Saraceno R., Kleyn C.E., Terenghi G., Griffiths C.E. The role of neuropeptides in psoriasis. Br J Dermatol 2006; 155: 876 -882

24. Ikoma A., Rukwied R., Ständer S. et al Neuronal sensitization for histamine-induced itch in lesional skin of patients with atopic dermatitis. Arch Dermatol 2003; 139: 1455-1458.

25. Ikoma A., Handwerker H., Miyachi Y., Schmelz M. Electrically evoked itch in humans. Pain 2005; 113: 148-154.

26. van Laarhoven A.I., Kraaimaat F.W., Wilder-Smith O.H. et al. Sensitivity to itch and pain in patients with psoriasis and rheumatoid arthritis. Exp Dermatol 2013; 22: $530-534$.

27. Han L., Dong X. Itch mechanisms and circuits. Annu Rev Biophys 2014; 43: 331-355.

28. Tominaga M., Takamori K. An update on peripheral mechanisms and treatments of itch. Biol Pharm Bull 2013; 36 (8): 1241-1247.
29. Crowley C., Spencer S.D., Nishimura M.C. et al. 42. Vaatainen N., Hannuksela M., Karvonen J. Local phoMice lacking nerve growth factor display perinatal loss of sensory and sympathetic neurons yet develop basal forebrain cholinergic neurons. Cell 1994; 76 (6): 1001-1011.

30. Albers K.M., Wright D.E. Davis B.M. Overexpression of nerve growth factor in epidermis of transegenic mice 44 causes hypertrophy of the peripheral nervous system. J Neurosci 1994; 14, 1422-1432.

31. Kimura H., Schubert D. Schwannoma-derived growth 45 . factor promotes the neuronal differentiation and surviva of PC12 cells. J Cell Biol 1992; 116 (3): 777-783.

32. Nilsson A., Kanje M. Amphiregulin acts as an auto- 46. Baldo A., Sammarco E., Plaitano R. et al. Narrowband crine survival factor for adult sensory neurons. Neuro- $\quad$ (TL-01) ultraviolet B phototherapy for pruritus in polyreport 2005; 16 (3): 213-218.

33. Dontchev V.D., Letourneau P.C. Nerve growth factor and 47. Lim H.W., Vallurupalli S., Meola T. et al. UVB phototherasemaphorin $3 \mathrm{~A}$ signaling pathways interact in regulat- $\quad$ py is an effective treatment for pruritus in patients infected ing sensory neuronal growth cone motility. J Neurosci with HIV. J Am Acad Dermatol. 1997; 37: $414-417$. 2002; 22 (15): 6659-6669.

34. Tominaga M., Kamo A., Tengara S. et al. In vitro mode for penetration of sensory nerve fibres on a Matrige basement membrane: implications for possible application to intractable pruritus. Br J Dermatol. 2009; 161 (5): 1028-1037.

35. Jekler J., Larkö 0. UVB phototherapy of atopic dermatitis. Br J Dermatol 1988; 119: 697-705.

36. Jekler J., Larkö 0. UVA-UVB versus UVB phototherapy for atopic dermatitis: A paired comparison study. J Am Acad Dermatol 1990; 22: 49—53.

37. von Kobyletzki G., Pieck C., Hoffmann K. et al. Medium-dose UVA1 cold-light phototherapy in the treat- 51 . ment of severe atopic dermatitis. J Am Acad Dermatol 1999; 41 (6): 931-937.

38. Krutmann J., Diepgen T.L., Luger T.A. et al. Highdose UVA1 therapy for atopic dermatitis: results of a multicenter trial. J Am Acad Dermatol 1998; 38 (4): 589-593.

39. Reynolds N.J., Franklin V., Gray J.C. et al. Narrowband ultraviolet B and broad-band ultraviolet A phototherapy in adult atopic eczema: a randomised controlled trial. Lancet 2001; 357 (9273): 2012-2016.

40. Clayton T.H., Clark S.M., Turner D., Goulden V. The treatment of severe atopic dermatitis in childhood with narrowband ultraviolet B phototherapy. Clin Exp Dermatol 2007; 32 (1): 28-33.

41. Karvonen J., Hannuksela M. Long term results of topical trioxsalen PUVA in lichen planus and nodular prurigo. Acta Derm Venereol Suppl [Stockh]. 1985; 120: 53—55. tochemotherapy in nodular prurigo. Acta Derm Venereol. 1979; 59: 544—547.

. Gambichler T., Hyun J., Sommer A. et al. A randomised controlled trial on photo(chemo)therapy of subacute prurigo. Clin Exp Dermatol 2006; 31: 348-353.

. Pothiawala S.Z., Baldwin B.T., Cherpelis B.S. et al. The role of phototherapy in cutaneous T-cell lymphoma. J Drugs Dermatol 2010; 9: 764—772.

. Kaptanoglu A.F., Oskay T. Ultraviolet B treatment for pruritus in Hodgkin's lymphoma. J Eur Academy Dermatol Venereol 2003: 17: 489—490.

(TL-01) ultraviolet B phototherapy for pruritus in pol
cythaemia vera. Br J Dermatol. 2002; 147: 979_-981.
py is an effective treatment for pruritus in patients infected
with HIV. J Am Acad Dermatol. 1997; 37: 414_417. phototherapy of uremic pruritus. Long-term results and possible mechanism of action. Ann Intern Med 1979: 91: 17-21.

49. Kamo A., Tominaga M., Tengara S. et al. Inhibitory effects of UV-based therapy on dry skin-inducible nerve growth in acetone-treated mice. J Dermatol Sci 2011; 62 (2): $91-97$

50. Tominaga M., Tengara S., Kamo A. et al. Psoralen-ultraviolet A therapy alters epidermal Sema3A and NGF levels and modulates epidermal innervation in atopic dermatitis. J Dermatol Sci 2009; 55: 40—46.

1. Wallengren J., Sundler F. Phototherapy reduces the number of epidermal and CGRP-positive dermal nerve fibres. Acta Derm Venereol 2004; 84 (2): 111-115.

52. Chen X., Yang M., Cheng Y. et al. Narrow-band ultraviolet B phototherapy versus broad-band ultraviolet psoriasis. Cochrane Database Syst Rev 2013 Oct 23:10:CD009481.

3. Racz E., Prens E.P. Phototherapy and photochemotherapy for psoriasis. Dermatol Clin 2015; 33: 79—89.

54. Katunina O.R., Chikin V.V., Znamenskaya L.F., Inoyatova L.A. Role of neuromediators in the development of skin irritation in patients with atopic dermatitis. Vestnik Dermatologii i Venerologii 2013; 5: 91-101. [Катунина О.Р., Чикин В.В., Знаменская Л.Ф., Иноятова Л.А. Роль нейромедиаторов в развитии воспаления в коже больных атопическим дерматитом. Вестн дерматол венерол 2013; (5): 91—101.] $B$ or psoralen-ultraviolet A photochemotherapy for

об авторах:

В.В. Чикин — К.М.Н., старший научный сотрудник ФГБУ «ГНЦДК» Минздрава России, Москва

М.Б. Жилова - к.м.Н., зав. отделением физиотерапии ФГБУ «ГНЦДК» Минздрава России, Москва

В.А. Смольянникова - д.м.н., профрессор кафедры патологической анатомии ГБОУ ВПО Первый МГМУ им. И.М. Сеченова

Минздрава России, Москва

М.А. Нефредова — врач-дерматовенеролог ФГБУ «ГНЦДК» Минздрава России, Москва

\section{Консликт интересов}

Авторы заявляют об отсутствии потенциального конфликта интересов, требующего раскрытия в данной статье 